\title{
BROWSE SHRUBS AND TREES AS FODDER FOR RUMINANTS: A REVIEW ON MANAGEMENT AND QUALITY
}

\author{
S. K. Oppong ${ }^{1}$, P.D. Kemp ${ }^{2}$ and G.B. Douglas ${ }^{3}$ \\ ${ }^{1}$ Faculty of Renewable Natural Resources, College of Agriculture and Natural Resources, \\ Kwame Nkrumah University of Science and Technology, Kumasi, Ghana \\ ${ }^{2}$ Institute of Natural Resources, Massey University, Palmerston North, New Zealand \\ ${ }^{3}$ AgResearch Grasslands, Private Bag 11008, Palmerston North, New Zealand
}

\begin{abstract}
This paper reviews the main determinants of productivity and quality of forage from browse species and highlights the usefulness of browse plants as fodder sources. The effect of secondary plant metabolites on forage quality and the consequential effects on browse acceptability and intake are presented. Condensed tannin (CT) is emphasised due to its nutritional advantage if it occurred at an acceptable level $(<50 \mathrm{gCT} /$ $\mathrm{kg} D \mathrm{DM})$. The practical implication of this limit has been questioned and it is speculated that it may vary with plant species as the function of CT depends on its structure and level of polymerisation. Gaps in our knowledge of browse plants are identified and areas requiring further research are indicated.
\end{abstract}

Keywords: Browse yield, Cutting, Browsing, Condensed tannin, Ruminants

\section{INTRODUCTION}

The leaves and soft stems of shrubs and trees (browse or topfeed) are important in ruminant nutrition (Gutteridge and Shelton, 1994). Browse may also include fruits and pods of shrubs and trees (Aganga and Tshwenyane, 2003). Browse use spans from the temperate to the tropical areas of the world, particularly in areas prone to drought (Lefroy et al., 1992), arid or semi-arid and montane zones of Africa (Otsyina and Mckell, 1985), AsianPacific regions (Brewbaker, 1986) and North America (McKell et al., 1972). Browse use has a long history (Robinson, 1985) but with the advent of cultivated pastures it has attracted less attention due to the advantages of cheaper establishment and easier management of herbaceous pastures.
The potential of browse species in ameliorating herbaceous feed shortages in livestock systems has been demonstrated empirically. However in practice, the provision of adequate and quality browse is beset with difficulties. Research results have been conflicting due to the diversity in experimental locations and sites, as well as the varied plant species used (Horne et al. 1986; Stur et al. 1994). It is the intent of this paper to recount the management and quality issues on browse species over the last four decades. The focus is on the main determinants of productivity and quality of forage from browse species and highlights the usefulness of browse species as fodder sources. Gaps in our knowledge of these useful plants are identified and areas requiring further research are indicated. 
Browse shrubs and trees as source of fodder for ruminants

Woody plants, usually low growing trees and shrubs, are useful fodder for livestock and wildlife.

They may be leguminous or non-leguminous, but leguminous plants are favoured because of their ability to fix nitrogen and their relatively high foliar nitrogen (protein) levels (Gutteridge and Shelton, 1994). Browse species provide flexibility in the timing of their use, and in particular provide green feed when grasses and other herbaceous materials are dry (Lefroy et al., 1992).

Compared to grasses, most leguminous fodder trees and shrubs have higher concentrations of crude protein, minerals and neutral detergent fiber (Dicko and Sikena, 1992), and generally a lower concentration of acid detergent fiber and dry matter digestibility (Le Houerou, 1980). Nutrient levels and digestibility of fodder trees and shrubs also decline slightly over the growing season and hence their potential value as drought fodder for livestock (Baumer, 1992). Furthermore, the early growing season of browse species occurs in the late dormant season of grasses (Bergstrom 1992) thus providing a potential early supplement to pasture. Recent work in Northern Australia showed that the addition of Leucaena leucocephala into pastures increased the quality and quantity of cattle diets resulting in increased animal production (McGowan and Matthews, 1992).

Many woody plants of the African savannas are browsed or topped for dry season feed for livestock such as sheep, goats and cattle (Le Houerou, 1980; Otsyina and McKell, 1985). Mabey and Rose Innes (1966) reported that cattle fed on Antiaris africana browse had weight gains of $82 \mathrm{~g} /$ day. In Australia, trees and shrubs such as Chamaecytisus palmensis and L. leucocephala, Acacia spp., Atriplex spp., Brachychiton populneum, and Salix spp are cultivated as fodder (Lefroy et al., 1992). Oldham et al. (1991) found that young ewes that grazed C. palmensis grew significantly more wool than their flockmates on supplemented dry pasture (Table 1). In Bangladesh, Kibria et al. (1994) found that goats fed leaves of Artocarpus sp and L. leucocephala gained weight at a rate of 43.9 and $52.8 \mathrm{~g} /$ day respectively. Further, in New Zealand browse species such as Ulex europaeus, C. palmensis and Salix species are used as supplementary fodder for sheep, goats and deer during summer drought (Borens and Poppi, 1990; Oppong et al., 2001).

\section{Management and quality of browse species}

The use of browse species involves defoliation either by cutting or by herbivory. The process has several implications for the productivity, quality of the forage and persistence of the species. The amount and type of tissue removed, and when the loss occurs in relation to plant development and the prevailing environment (Richards, 1993), are most important in determining the impact of defoliation on plants (Crawley, 1983). Loss of meristematic tissues usually has a much greater effect on regrowth than the proportional loss of biomass, leaf area or plant resource (Richards, 1993).

There is usually a decline in total non-structural carbohydrates of roots and remaining shoot parts after defoliation (George and Mckell, 1978). Donart and Cook (1970) found that the defoliation of herbaceous plants early in the growing season was more detrimental than late in the season while the reverse trend occurred in browse plants. The depletion of

Table 1: The mean ( \pm sem) clean fleece weight $(\mathrm{CFW})$ and mean $( \pm$ sem) fibre diameter $(\mathrm{FD})$ of young ewes grazed on Chamaecytisus palmensis or dry pasture over summer/autumn

\begin{tabular}{lccc}
\hline Forage type & No. of Ewes & CFW (kg) & FD (mm) \\
\hline Chamaecytisus palmensis (31 weeks) & 27 & $3.0(0.08)$ & $21.3(0.22)$ \\
Pasture & 30 & $2.2(0.05)$ & $20.5(0.21)$
\end{tabular}

Adapted from Oldham et al. (1991)

66 Journal of Science and Technology, Vol. 28, No. 1, April 2008 
stored reserves caused by excessive defoliation results in reduced vigour and plant growth and in extreme cases can result in death of plants.

Plants also react to herbivory by providing protection from grazing through the production of toxins or morphological features such as toughness or spines and by compensating for the biomass removed (Bergstrom and Danell, 1987). Thus compensatory growth in plants may alleviate the potential deleterious effects of tissue damage, whether to vegetative or reproductive organs (McNaughton, 1983). Danell et al. (1985) reported that browsed birches produced shoots with larger and more chlorophyll-rich leaves than did unbrowsed birches. Further, Du Toit et al. (1990) also noted that shoot regrowth in heavily browsed Acacia nigrescens more than compensated for herbivory, as net annual shoot extension was not significantly different from that in lightly browsed trees.

\section{Browse productivity}

Forage yield from browse species is affected by several interacting factors, some of which are too complex to manipulate. In general, browse yield is affected by climate, soil, plant spacing, plant stock used, management history, age of plant at harvest and herbivory. Climate is difficult to manipulate except for the use of irrigation to overcome soil moisture deficits due to inadequate rainfall. The other factors can be altered relatively easily but the practical expediency of such intervention depends on critical factors such as the profitability and percent yield increment. Most browse yield data have not been reported with the associated ages of the plants at the time of harvest, which reduces their value for proper utilisation assessment (Skerman et al., 1988) and also for comparing yields among species and even within species. Tree age influences yield by its effect on root development and distribution (Adejumo, 1992) and stump diameter (Blake, 1983). Increased stump diameter may result in increased potential growing buds, which affects coppicability and yield from cut plants. Browse yield data for some browse species in tropical, subtropical and temperate regions of the world are presented in Table 2.

Table 2: Browse yield from legume and non-legume species

\begin{tabular}{|c|c|c|c|c|}
\hline Legume species & Plant part & $\begin{array}{c}\text { Age at } \\
\text { harvest }\end{array}$ & $\begin{array}{c}\text { Yield tDM/ } \\
\text { ha/yr }\end{array}$ & Source \\
\hline Gliricidia sepium & leaf & & $2-20$ & Simons and Stewarts, 1994 \\
\hline Luecaena leucocephala & leaf+soft stem & & $3-30$ & Shelton and Brewbaker, 1994 \\
\hline Sesbania spp & leaf+soft stem & & $4-12$ & Gutteridge, 1994 \\
\hline Calliandra calothyrus & leaf+soft stem & & $7-10$ & Palmer et al. 1994 \\
\hline Albizia lebbeck & leaf+soft stem & & $1.7-2.5$ & Lowry et al. 1994 \\
\hline Chamaecytisus palmensis & leaf+soft stem & $\begin{array}{l}1 \text { year } \\
4 \text { years }\end{array}$ & $\begin{array}{r}3-9 \\
2.9 \\
14\end{array}$ & $\begin{array}{l}\text { Lefroy et al. } 1994 \\
\text { Douglas et al. } 1996 \\
\text { Snook, } 1994\end{array}$ \\
\hline Non-legumes species & & & & \\
\hline Salix matsudana $\mathrm{x}$ alba & leaf+soft stem & $\begin{array}{l}1 \text { year } \\
3 \text { years } \\
4 \text { years } \\
5 \text { years }\end{array}$ & $\begin{array}{r}1.1 \\
3.0 \\
4.7 \\
2.7-7.1\end{array}$ & $\begin{array}{l}\text { Douglas et al. } 1996 \\
\text { Oppong et al. } 1996 \\
\text { Oppong et al. } 2001 \\
\text { Hathawy, } 1986\end{array}$ \\
\hline $\begin{array}{l}\text { Salix kinuyanagi } \\
\text { Populus spp }\end{array}$ & $\begin{array}{l}\text { leaf+soft stem } \\
\text { leaf+soft stem }\end{array}$ & $\begin{array}{l}1 \text { year } \\
3 \text { years } \\
4 \text { years }\end{array}$ & $\begin{array}{r}1.7 \\
2.3 \\
2.9 \\
0.2-1.0\end{array}$ & $\begin{array}{l}\text { Douglas et al. } 1996 \\
\text { Oppong et al. } 1996 \\
\text { Oppong et al. } 2001 \\
\text { Anon, } 1995\end{array}$ \\
\hline
\end{tabular}




\section{Effects of cutting on browse yield and quality}

The effects of cutting height and frequency on yield and nutritional quality of forage from many browse plants have not exhibited a consistent pattern. Cutting height usually did not influence forage yield, but cutting frequency exerted greater effect on yield (Stur et al., 1994).

However, Tarawali et al. (1996) observed that in Gliricidia sepium lower cutting heights $(30 \mathrm{~cm})$ yielded more dry matter than those cut at $50 \mathrm{~cm}$ and $70 \mathrm{~cm}$ during the first harvest. Defoliation responses usually occur within a limited range of stump height, below or above which cutting height has no influence on yield and quality of forage. For example, Catchpole and Blair (1990) reported that leaf yield of Leucaena leucocephala was unaffected by cutting heights of $1.5-2.5 \mathrm{~m}$ above ground.

Guevaria et al. (1978) also found increased dry matter yield with less frequent cutting of L. leucocephala. Dry matter yield of L. leucocephala declined (Karim et al., 1991) with frequent cutting due to an increased number of recovery phases, which affected the recovery of carbohydrate reserves and lowered the rate of dry matter production (Erdmann et al., 1993). Erdmann et al. (1993) reported a significantly greater number of shoots on Gliricidia sepium cut at $25 \mathrm{~cm}$ above ground compared to those cut at $100 \mathrm{~cm}$. They attributed the difference to the $100 \mathrm{~cm}$ stools not having to grow the same quantity of leaves, as many of them were retained on the stumps, while the $25 \mathrm{~cm}$ stools were devoid of leaves. In contrast, a similar study on L. leucocephala showed a greater number of shoots on stools cut at $90-\mathrm{cm}$ (Jama and Nair, 1989) compared to $30 \mathrm{~cm}$ cutting height.

Everitt (1983) noted that the crude protein (CP) and phosphorus $(\mathrm{P})$ concentration in regrowth of Celtis pallida, Zanthoxylum fagora, and Ziziphus obtusifolia cut on various dates were higher than in current growth from uncut plants, at two months after cutting. Cutting created nutritious sprouts that were more palatable and readily available due to reduced plant height and restrictions to browsing such as sharp thorns, often prevalent on mature stems.

\section{Effects of browsing on browse yield and quality} A plant's response to browsing depends on plant genetics, development stage, intensity and frequency of defoliation, plant parts affected, and modifying effects of environmental factors (Teague, 1985). The consequences of grazing intensity and frequency on individual plants and plant communities are well documented (Vallentine, 1990). For example, In South Africa, Du Toit et al. (1990) compared heavily and lightly browsed trees of Acacia nigrescens and found that the net shoot extension was not significantly different between heavy and light browsing by giraffe and impala. The heavily browsed trees grew rapidly to compensate for the frequent removal of browse and had reduced condensed tannin (CT) levels and higher $\mathrm{N}$ and $\mathrm{P}$ contents in leaves compared with the lightly browsed trees.

Heavy and less frequent browsing of Coleogyne ramosissima by goats (Provenza et al., 1983) and Betula species by moose (Danell et al., 1985) increased forage yield and quality compared to unbrowsed plants. Less frequently browsed plants outyielded those browsed frequently, and had forage which was lower in CT (Provenza et al., 1983; Danell et al., 1985).

\section{Nutritive value of browse for ruminants}

Nutritive value encompasses all nutritional attributes of forage in relation to its overall value to the consuming animal (Van Soest, 1994). This term is often used in a restrictive sense of forage quality (Mertens, 1994) or feeding value (Ulyatt, 1973), including protein content and digestibility. Digestibility is a major determinant of nutritive value (Ulyatt, 1973) and provides the best practical evaluation of the quality of the animal's diet (Holechek et al., 1982). The nutritive values of some browse species are shown in Table 3. These values are normally given without indicating the age of the material chemically analysed and which in no 
Table 3: Nutritive value of legume and non-legume browse species

\begin{tabular}{|c|c|c|c|c|}
\hline Gliricidia sepium & leaf & $20-30$ & $60-65$ & Simons and Stewarts, 1994 \\
\hline Sesbania spp & leaf+soft stem & $20-25$ & $66-75$ & Gutteridge, 1994 \\
\hline Albizia lebbeck & leaf+soft stem & $16-23$ & $45-70$ & Lowry et al. 1994 \\
\hline Salix matsudana $\mathrm{x}$ alba & leaf+soft stem & 14 & 68 & Oppong et al. 1996 \\
\hline Salix kinuyanagi & leaf + soft stem & 12 & 61 & Oppong et al. 1996 \\
\hline Populus spp & leaf+soft stem & $13-15$ & $66-70$ & Anon, 1995 \\
\hline
\end{tabular}

doubt may influence these values especially that of nitrogen (protein). More active tissues usually have greater quality. For example, live leaf has higher quality than live stem (Oppong et al., 2001) because of the higher photosynthetic activity. Nutrient quality declines with decreasing rate of development and the outset of senescence.

\section{Effect of secondary plant metabolites on rumi- nants}

Most browse plants contain diverse secondary metabolites that can deter animals from feeding on the foliage. Secondary metabolites vary in their potency as anti-feedants (Bryant et al., 1992), primarily due to toxicity of the metabolites rather than digestion inhibition (Bryant et al., 1991). Common secondary plant metabolites are presented in Table 4 (Barry and Blaney, 1987). Secondary metabolites have evolved as a defence mechanism of woody plants against herbivory. This is an adaptive mechanism used by woody plants growing on low fertility soils (Jackson et $a l ., 1996)$ to compensate for their inability to grow rapidly beyond the reach of most browsing animals. Of all the secondary plant metabolites that affect the quality of browse, soluble phenolics occur most widely in woody plants, with tannins receiving the most attention (Rittner and Reed, 1992). Tannins occur either as hydrolysable or condensed tannins, but the dominant forage tan-

Table 4: Common secondary compounds affecting the feed value of forages

\begin{tabular}{ll}
\hline Class & Examples \\
\hline Alkaloids & Pyrrolidizine alkaloids, Fescue alkaloids \\
Glycosides & Cyanogenic glycosides, Coumarin, \\
& Isoflavones and coumestins \\
Mycotoxins & Zearalenone, Trichothecenes, \\
& Sporidesmin, Phomopsin, Lolitrems, \\
& Swainsonine, Slaframine, Ergot alkaloids. \\
Polyphenols & Tannins \\
Proteins and Amino acids & Bloat-producing protein, \\
& Mimosine, Indospicine \\
Simple acids and their salts & Oxalates, Nitrates, Fluoroacetate \\
Steroids and terpenes & Saponins \\
\hline
\end{tabular}

Adapted from Barry and Blaney (1987) 
nins are usually of the condensed type (Kumar and Singh, 1984) in woody plants (Rittner and Reed, 1992). Examples of browse species with varying concentrations of condensed tannins (CT) are presented in Table 5. CT at low concentrations (20-40 g/kg DM) are nutritionally beneficial through decreased degradation of dietary protein in the rumen, and increased protein availability for digestion and absorption leading to good animal performance (Waghorn et al., 1990).

Many evergreen shrubs such as Artemisia spp. and Quercus spp. have high (> $76 \mathrm{gCT} / \mathrm{kgDM}$ ) levels of CT and other anti-nutritional factors. In woody plants, results indicate a negative correlation between CT content and palatability. CT binds forage protein and reduce their availability and digestibility, and they also restrict microbial fermentation of structural carbohydrates (Van Soest, 1994).

Some studies have used polyethylene glycol (PEG) to bind with CT thereby enabling the effects of $\mathrm{CT}$ to be determined by comparing responses from CT (no PEG) and non-CT (+PEG) treatments (Barry and Blaney, 1987). This technique was used to determine that high concentrations of CT $(60-90 \mathrm{~g} / \mathrm{kg}$ DM) in Lotus pedunculatus depressed cell wall digestion, voluntary intake and liveweight gain while low concentrations (20-
$40 \mathrm{gCT} / \mathrm{kg}$ DM) improved nutrient utilisation by ruminants. The latter occurred principally by reducing forage protein degradation in the rumen, thus simultaneously eliminating bloat and increasing amino acid supply to the animal (Barry and Blaney, 1987; Waghorn et al., 1990; Jackson et al., 1996).

Nastis and Malechek (1981) found reduced voluntary intake and digestibility of cell constituents in goats' fed Quercus browse with high CT concentration. Daily drenching of sheep fed leaves of Acacia aneura with PEG (Jones and Wilson, 1987), or brushtail possum (Cork, 1984) fed eucalyptus, resulted in increased food intake and cell wall digestion. Sheep and steers grazing Sericea lespedeza consumed more of the low CT containing plants than those with high CT concentrations (Kumar and Singh, 1984).

Our knowledge of the attributes of CT in woody species is limited making it difficult to extend the implications of CT values of herbaceous forages on ruminants to browse. Cautiously we are inclined to believe that the limit $(<50 \mathrm{gCT} / \mathrm{kg} \mathrm{DM})$ set as a rule of thumb for any nutritional benefit (Waghorn et al., 1990) may not be appropriate for all forages. We suggest that the nutritionally beneficial CT level should be set for different types of forages. Kumar and Singh (1984) reported anomalies in the digesti-

Table 5: Condensed tannin (CT) concentration (g/kg DM) in leaves harvested from browse species (estimates from butanol-HCl method; samples were prepared by freeze drying)

\begin{tabular}{lc}
\hline Species & Total CT (g/kg DM) \\
\hline Acacia boliviana & 17.5 \\
Arachis pintoi & 33.6 \\
Calliandra calothyrus & 57.8 \\
Cassia sp. & 93.2 \\
${\text { Flemingia macrophylla }(17405)^{*}}_{\text {Gliricidia sepium }}$ & 240.1 \\
Leucaena diversifolia & 40.7 \\
Leucaena leucocephala cv Cunningham & 92.5 \\
Leucaena pallida & 60.3 \\
Tadehagi triquetrum & 67.2 \\
\hline
\end{tabular}

*Accession number; Adapted from Jackson et al. 1996

70 Journal of Science and Technology, Vol. 28, No. 1, April 2008 
Oppong et al.

bility of proteins of various tree leaves and explained that these may be due to the type of tannin, protein precipitation capacity and degree of polymerization. Our contention is that the CT of woody plants may be functionally different to that of herbaceous plants since the structure and extent of polymerisation of CT determines its biological activity (Kumar and Singh, 1984; Clausen et al., 1990). Moreover, chemical defenses of woody plants vary by growth stage and by plant parts with growth stages. For example, the buds and internodes of young and adult stages of Betula resinifera differ in chemical defenses (Bryant et al., 1991).

\section{Secondary metabolites and selective behaviour of ruminants}

Ruminants select a diet from the plants available to them (Gordon and Lascano, 1993). The grazing process is a system of diet selection interacting with the animals' physiological needs. That is, animals seek the most energy-efficient sources of forage (Stuth, 1991). The discriminatory nature of herbivore in the choice of forage is mainly due to quality and chemical defence of the forage plants. Abundant evidence shows that food selection and ingestion is regulated by toxins rather than by inhibition of protein or carbohydrate digestion (Bryant et al., 1991).

Little information exists on diet selection by ruminants faced with conflicting constraints that may arise from the presence of secondary plant compounds. For example, plants with high levels of CT may contain high level of nutrients and energy, but the astringent sensation animals probably experience when consuming them may lead to their rejection, which could be a nutritional mistake (Provenza et al., 1991). The rejection of CT containing plants or plant parts is presumably an evolved response by animals to the negative effects tannins have on forage digestibility and therefore animal fitness (Rhoades, 1979). Studies of domestic and wild animals fed unpalatable browse normally available to them, or artificial diets treated with extracts from this browse, confirm the importance of toxicity (Bryant et al., 1991).

\section{CONCLUSIONS AND RESEARCH NEEDS}

Browse species are potentially indispensable and nutritionally beneficial components of the animal's environment and they must be given due research attention. Data on the management and use of browse species are conflicting, therefore, the feed advantage of browse compared to alternative feed sources is disputed (Oppong, 1998). Several trials have been conducted in semi-arid to arid areas of the tropics, with few in temperate regions. Numerous potential browse species are available in temperate areas, which should be thoroughly studied to generate data for the development of appropriate managements for these plants to provide good quality fodder for dry periods in these areas.

Browse species react differently to cutting and browsing and any species evaluation must be based on both management techniques. Preference studies on browse species will determine the most nutritionally beneficial species for ruminants and based on the preference rating species could be selected for cultivation.

Systematic effort should be made to evaluate in detail known browse species for their yield potential and fodder quality. Studies are required into improving browse yield through (a) breeding of browse species that are fast growing and high yielding, amenable to browsing through low canopy formation and improved morphology to enhance accessibility and persist under intense and frequent use, and (b) respond to soil amendments such as fertilisation. More animals' responses on browse should be determined. The effect of browse species on associated species, especially in a tree-pasture system also deserves systematic study. The importance of secondary plant metabolites especially condensed tannins should be studied, as woody plants tend to have high concentrations of $\mathrm{CT}$ and their nutritional role in ruminant production systems need more attention.

\section{ACKNOWLEDGEMENT}

We acknowledge with thanks the financial support from the New Zealand Commonwealth Scholarship Scheme, Massey University Research Funds and the 
Foundation for Research, Science and Technology. We are also grateful to all staff of the Plant Science Department, Massey University, Palmerston North; New Zealand Horticultural Research, Aokautere, Palmerston North and AgResearch Grasslands, Palmerston North, New Zealand for their help.

\section{REFERENCES}

Adejumo, J. O. (1992). Effect of plant age and harvest date in the dry season on yield and quality of Gliricidia sepium in Southern Nigeria. Tropical Grasslands 26:21-24

Anonymous (1995). Poplar Agroforestry: an introduction to using poplar for timber. New Zealand Poplar Commission, HortResearch's Aokautere Research Centre, Palmerston North, $17 \mathrm{p}$.

Aganga, A. A. and Tshwenyane, S.O. (2003). Feeding values and anti-nutritive factors of forage tree legumes. Pakistan Journal of Nutrition 2 (3): 170-177.

Barry, T. N. (1989). Condensed tannins: Their role in ruminant protein and carbohydrate digestion and possible effects upon the rumen ecosystem. Pp 153-169 in: The role of Protozoa and Fungi in Ruminant Digestion, Nolan, J. V., Leng, R., Demeyer, D. L. ed. Proceedings of an International Seminar sponsored by the OECD Co-operative Research Project on Food Production and Preservation, and the University of New England, Australia.

Barry, T. N. and Blaney, B. J. (1987). Secondary compounds of forages. In: Hacker JB; Ternouth JH eds. The nutrition of herbivores. Proceedings of the 2nd International Symposium on the Nutrition of Herbivores, pp 65119.

Baumer, A. (1992). Trees as browse and to support animal production. In: Andrew Speedy; Pierre-Luc Pugliese eds. Legume trees and other fodder trees as protein sources for livestock 1418 October 1991. Mardi, Kuala Lumpur, Malaysia. F.A.O-UN, Rome. F.A.O Animal Production and Health paper 102: 1-9.
Bergstrom, R. (1992). Browse characteristics and impact of browsing on trees and shrubs in Africa. Journal of Vegetation Science 3: 315-324.

Bergstrom, R. and Danell, K. (1987). Effects of simulated winter browsing by moose on morphology and biomass of two birch species. Journal of Ecology 75:533-544

Blake, T. J. (1983). Coppice systems for shortrotation intensive forestry: the influence of cultural, seasonal, and plant factors. Australian Journal of Forestry Research 13: 279-291.

Borens, F. M. P. and Poppi, D. P. (1990). The nutritive value forruminants of tagasaste (Chamaecytisus palmensis), a leguminous tree. Animal Feed Science and Technology 28: 275 292.

Brewbaker, J. L. (1986). Leguminous trees and shrubs for Southeast Asia and the South pacific agriculture. Blair, G. J., Ivory, D. A. and Evans, T. R. eds. Forages in Southeast Asian and South pacific agriculture. 19-23 august 1985. Cisarua, Indonesia. ACIAR Proceeding series, Canberra, A.C.T 2601 12: 43-50.

Bryant, J. P., Provenza, F. D., Pastor, J., Reichardt, P. B., Clausen, T. P., Du Toit, J. T. (1991). Interactions between woody plants and browsing mammals mediated by secondary metabolites. Annual Reveiw of Ecological Systems 22: 431 446.

Bryant, J. P., Reichardt, P. B. and Clausen, T. P. (1992). Chemically mediated interactions between woody plants and browsing mammals. Journal of Range Management 45: 18-24.

Cathpoole, D. W. and Blair, G. J. (1990). Forage tree legumes. I. Productivity and N economy of Leucaena, Gliricidia, Calliandra and Sesbania and tree/green panic mixtures. Australian Journal of Agricultural Research 41: 521-530.

Clausen, T. P., Provenza, F. D., Burrit, E. A., Reichardt, P. B. and Bryant, J. P. (1990). Ecological implications of condensed tannin structure: A case study. Journal of Chemical Ecology 16: 2381-2392. 
Cork, S. J. (1984). Utilisation of Eucalyptus foiliage by arboreal marsupials. Proceedings of the Nutrition Society of Australia 9:88-97

Crawley, M. J. (1983). Herbivory: The dynamics of animal-plant interactions. Blackwell, Oxford, $437 p$.

Danell, K., Huss-Danell, K. and Bergstrom, R. (1985). Interaction between browsing moose and two species of birch in Sweden. Ecology 66: $1867-1878$.

Dicko, M. S. and Sikena, L. K. (1992). Feeding behaviour, quantitative and qualitative intake of browse by domestic ruminants. In: Andrew Speedy and Pierre-Luc Pugliese eds. Legume trees and other fodder trees as protein sources for livestock 14-18 October, 1991 Mardi, Kuala Lumpur,Malaysia. F.A.O-U.N, Rome. F.A.O Animal Production and Health paper 102: 129-144.

Donart, G. B. and Cook, C. W. (1970). Carbohydrate reserve content of mountain range plants following defoliation and regrowth. Journal of Range Management 23:15-19.

Douglas, G. B., Bulloch, B. T. and Foote, A. G. (1996). Cutting management of willows (Salix spp.) and leguminous shrubs for forage during summer. New Zealand Journal of Agricultural Research 39: 175-184.

Du Toit, J. T., Bryant, J. P. and Kathleen, F. (1990). Regrowth and palatability of Acacia shoots following pruning by African browsers. Ecology 71: 149-154.

Erdmann, T. K., Nair, P. K. R. and Kang, B. T. (1993). Effects of cutting frequency and cutting height on reserve carbohydrates in Gliricidia sepium (Jacq.) Walp. Forest ecology and management 57:45-60.

Everitt, J. H. (1983). Effects of plant shredding on nutrient content of four South Texas deer browse species. Journal of range management 36: 779-781.
George, M. R. and McKell, C. M. (1978). Distribution of food reserves in snowberry (Symphoricarpus oreophilus). Journal of Range Management 31: 101-104.

Gordon, I. J. and Lascano, C. (1993). Foraging strategies of ruminant livestock on intensively managed grasslands:potential and constraints. Proceedings of the XVII International Grassland Congress, New Zealand: 681-690

Gueverra, A. B., Whitney, A. S. and Thompson, J. R. (1978). Influence of intra-row spacing and cutting regime on growth and yield of leucaena. Agronomy Journal 70: 1033-1037.

Gutteridge, R. C. (1994). The perennial Sesbania species. In: Gutteridge, R. C. and Shelton, H. M. eds. Forage Tree Legumes in Tropical Agriculture, CAB International, UK, pp 49-64.

Gutteridge, R. C. and Shelton, H. M. eds. (1994). The role of forage tree legumes in cropping and grazing systems. Forage Tree Legumes in Tropical Agriculture, CAB International, UK, pp 3-11.

Hathaway, R. L. (1986). Short-rotation coppiced willows for sheep fodder in New Zealand. New Zealand Journal of Agricultural Science 20:140-142

Holechek, J. L., Vavra, M. and Pieper, R. D. (1982). Methods for determining the nutritive value quality of range ruminant diets: A review. Journal of Animal Science 54: 363-376.

Horne, P. M., Catchpole, D. W. and Ella, A. (1986). Cutting management of tree and shrub legumes. In: Blair, G. J., Ivory, D. A. and Evans, T. R. ed. Forages in south Asian South Pacific Agriculture, Australian Centre for International Agricultural Research Proceedings series, number 12 Canberra. pp 51-54

Tarawali G., Iji P.A., Chionuma P.C. and Obot, U. (1996). Herbage yield and quality of Gliricidia sepium under different cutting heights and defoliation frequencies Agroforestry Systems 34:315-326 
Jackson, F. S., Barry, T. N., Lascano, C. and Palmer, B. (1996). The extractable and bound condensed tannin content of leaves from tropical tree, shrub and forage legumes. Journal of the Science of Food and Agriculture 71:103110.

Jama, B. and Nair, P. K. R. (1989). Effect of cutting height of Leucaena leucocephala hedges on production of seeds and green leaf manure at Machakos, Kenya. Leucaena Research reports 10: 46-68.

Jones, D. I. H and Wilson, A. D. (1987). Nutrtive quality of forage. In: Hacker, J. B. and Ternouth, J. H. eds. The nutrition of herbivores. Academic press, Auatralia, pp 65-89.

Karim, A. B., Rhodes, E. R. and Savill, P. S. (1991). Effect of cutting height and cutting interval on dry matter yield of Leucaena leucocephala (Lam) De Wit. Agroforestry Systems 16:129-137.

Kibria, S. S., Nahar, T. N. and Mia, M. M. (1994). Tree leaves as alternative feed resources for Black Bengal goats under stall fed conditions. Small Ruminant Research 13: 217-222

Kumar, R. and Singh, M. (1984). Tannins: Their adverse role in ruminant nutrition. Journal of Agriculture and Food Chemistry 32: 447-453.

Lefroy, E. C., Dann, P. R., Wildin, J. H., WesleySmith, R. N. and McGowan, A. A. (1992). Trees and shrubs as sources of fodder in Australia. Agroforestry Systems 20:117-139.

Le Houerou, H. N. (1980). Chemical composition and nutritive value of browse in West Africa. In: Le Houerou, H. N. ed. Browse in Africa. The current state of Knowledge. ILCA, Addis Ababa, pp 261-290.

Lowry, J. B., Prinsen, J. H. and Burrows, D. M. (1994). Albizia lebbeck - a promising forage tree for semiarid regions. In: Gutteridge RC and Shelton HM eds. Forage Tree Legumes in Tropical Agriculture, CAB International, UK, pp 75-83.

Mabey, G. L. and Rose Innes, R. (1966). Studies on browse plants in Ghana. II. Digestibility. (c) Digestibility of Antiaris africana from the Accra plains, using local cattle as experimental animals. Experimental Agriculture 2: 2732

McGowan, A.A. and Mathews, G. L. (1992). Forage production from hedges of tagasaste in a high rainfall temperate environment and the effects of plant spacing and frequency of harvesting. Australian Journal of Experimental Agriculture 32:633-640.

McKell, C. M., Blaisdell, J. P. and Gooding, J. R. (1972). Wildland Shrubs: Their biology and utilization. July 1971. Uta State University, Logan, Utah USDA forest service. General Technical Report - INT-1.

McNaughton, S. J. (1983). Compensatory plant growth as a response to herbivory. Oikos 40: 329-336

Mertens, D. R. (1994). Regulation of forage intake. In: Fahey, G. C. ed. Forage quality, evaluation and utilisation. National conference, University of Nebraska, Lincoln, USA, pp 450-493.

Nastis, A. S. and Malechek, J. C. (1981). Digestion and utilisation of nutrients in oak browse by goats. Journal of Animal Science 53:283-289.

Oldham, C., Allen, G. and Moore, P. (1991). Animal production from tagasaste growing in deep sands in a $450 \mathrm{~mm}$ winter rainfall zone. W. A. Journal of Agriculture 32: 24-30.

Oppong, S.K. (1998). Growth, Management and Nutritive value of willows (selex spp.) and other browse species in Manawatu, New Zealand. Ph.D thesis, Massey University, Palmerston, North, New Zealand, 170p.

Oppong, S., Kemp, P. D., Douglas, G. B. and Bulloch, B. T. (1996). Management of browse plants as drought fodder for sheep: a preliminary study. Proceedings of the New Zealand Grassland Association 58: 93-97.

Oppong, S. K., Kemp, P. D., Douglas, G. B. and Foote, A. G. (2001). Browse yield and nutritive value of two Salix species and 
Dorycnium rectum in New Zealand Agroforestry Systems 51: 11-21

Otsyina, R. M. and McKell, C. M. (1985). Browse in the nutrition of livestock: A Review. World Animal Review 33-39.

Palmer, B., Macqueen, D. J. and Gutteridge, R. C. (1994). Calliandra calothyrsus - a multipurpose tree legume for humid locations. In: Gutteridge, R. C. and Shelton, H. M. eds. Forage Tree Legumes in Tropical Agriculture, $\mathrm{CAB}$ International, UK, pp 65-74.

Provenza, F. D., Malechek, J. C., Urness, P. J. and Bowns, J. E. (1983). Some factors affecting twig growth in blackbrush. Journal of Range Management 36:518-520

Provenza, F. D., Burritt, E. A., Clausen, T. P., Bryant, J. P. and Reichardt, P. B. (1991). Conditioned flavour aversion: A mechanism for goats to avoid condensed tannins in blackbrush. The American Naturalist 136: 810-828.

Rhoades, D. F (1979). Evolution of plant chemical defense against herbivore. In: Rosenthal GA and Janzen, D.H. eds. Herbivore interactions with secondary plant metabolites. Academic press, New York pp 4-54.

Richards, J. H. (1993). Physiology of plants recovering from defoliation. Grasslands for our world pp 46-54.

Rittner, U. and Reed, J. D. (1992). Phenolics and in-vitro degradability of protein and fibre in West African browse. Journal of Science, Food and Agriculture 58:21-28.

Robinson, P. J. (1985). Trees as fodder crops. In: Cannell, M. G. R. and Jackson, J. E. eds. Attributes of trees as crop plants. Institute of terrestrial ecology, Natural Environment Research Council. UK, pp 281-300.

Shelton, H. M. and Brewbaker, J. L. (1994). Leucaena leucocephala - the most widely used forage tree legume. In: Gutteridge, R. C. and Shelton, H. M. eds. Forage Tree Legumes in Tropical Agriculture, CAB International, UK, pp 15-29.
Simons, A. J. and Stewart, J. L. (1994). Gliricidia sepium - a multipurpose forage tree legume. In: Gutteridge, R. C. and Shelton, H. M. eds. Forage tree legumes in tropical agriculture, $\mathrm{CAB}$ International, UK, pp 30-48.

Skerman, P. J., Cameron, D. G. and Riveros, F. (1988). Tropical forage legumes. 2nd edition. Food and Agriculture Organisation of the United Nations, Rome, 692p.

Snook, L. C. (1986). Tagasaste-Tree Lucerne, high production fodder crop. Night Owl, Shepparton, Victoria, Australia. 102p

Stur, W. W., Shelton, H. M. and Gutteridge, R. C. (1994). Defoliation management of forage tree legumes. In: Gutteridge, R. C. and Shelton, H. M. eds. Forage tree legumes in tropical agriculture. CAB International, U.K, pp 158-167.

Stuth, J. W. (1991). Foraging behaviour. In: Heitschmidt, R. K. and Stuth, J.W. eds. Grazing management: An ecological perspective pp 6583.

Teaque, W. R. (1985). Leaf growth of Acacia karoo trees in response to frequency and intensity of defoliation. In: Tothill, J. C. and Mott, J. J. eds. Ecology and Management of the World Savannas. Australian academy of science, Canberra, pp 220-222.

Ulyatt, M. J. (1973). The feeding value of herbage. In: Butler GW and Bailey RW eds. Chemistry and Biochemistry of herbage. Academic press, London and New York pp 3:131-178.

Vallentine, J. F. (1990). Grazing Management. Academic Press, Inc. USA. 533p.

Van Soest, P. J. (1994). Nutritional ecology of the ruminant. 2nd edition, Cornell University Press. USA.476p.

Waghorn, G. C., Jones, W. T., Shelton, I. D. and McNabb, W. C. (1990). Condensed tannins and the nutritive value of herbage. Proceedings of the New Zealand Grassland Association 51:171 $-176$. 